\title{
Atypical Hemorrhagic Presentation of a Fourth Ventricle Subependymoma: Case Report
}

\author{
Federico LANDRIEL, ${ }^{1}$ Cristina BeSAdA, ${ }^{2}$ Matías Migliaro, ${ }^{2}$ Silvia Christiansen, ${ }^{3}$ \\ Ezequiel GOLDSCHMIDT, ${ }^{1}$ Claudio YAMPOLSKY, ${ }^{1}$ and Pablo AJLER ${ }^{1}$
}

Departments of ${ }^{1}$ Neurosurgery, ${ }^{2}$ Radiology, and ${ }^{3}$ Anatomopathology, Hospital Italiano de Buenos Aires, Argentina

\begin{abstract}
To present a case of a fourth ventricle subependymoma (SE) with a spontaneous acute subarachnoid intra-cisternal bleeding. A 33-year-old man was admitted with 5 days history of oppressive occipital headache and neck pain without additional neurological focus. Unenhanced computed tomography (CT) scan demonstrated an isointense mass located in the fourth ventricle with a spontaneously hyperdense acute extratumoral hemorrhage in the cisterna magna. Contrast-enhanced magnetic resonance imaging (MRI) revealed a well-delimitated non-enhanced tumor, hypointense on $T_{1}$-weighted and hyperintense on $T_{2}$ weighted images, involving the floor of the fourth ventricle and extending caudally into the cervical spinal canal via foramen magnum. Intraoperative, a large blood clot was removed and a macroscopically hypovascularlesion was completely excised from the right lateral recess and the floor of the fourth ventricle. Intra and postoperative immuno-histopathological examination revealed a SE. The patient has a normal postoperative course and was discharged in the fifth postoperative day. A 10-month postoperative MRI study confirmed a complete tumor resection. Symptomatic SEs should be surgically treated emphasizing the urgency in the presence of hemorrhage. The interest of this case is to demonstrate that infratentorial SEs although extremely rare, might present with acute subarachnoid bleeding.
\end{abstract}

Key words: cisterna magna hemorrhage, fourth ventricle subependymoma, hemorrhagic subependymoma

\section{Introduction}

Subependymomas (SEs) are ependymal tumors developed from subependymal glial precursors and characterized by an asymptomatic benign clinical course and distinguished from the ordinary ependymomas by their general better prognosis. These rare tumors are more frequent in men predominantly adults with a general incidence accounting from $0.2 \%$ to $0.7 \%$ of intracranial tumors. ${ }^{8,10,11,14,15)}$ They commonly arise along the ventricular system walls, encountered in the $50-60 \%$ of the cases in the fourth ventricle, followed by the lateral ventricle $30-40 \%$, and less frequently, in the septum pellucidum area and spinal cord. ${ }^{13,16)}$ If symptoms are present, there are generally related with the obstruction of cerebrospinal fluid (CSF) pathway. ${ }^{6,8,9)}$ Tumoral-related hemorrhage represents an extremely rare presentation sign generally associated with intralesional bleeding that may cause acute and severe neurological deficits. ${ }^{2)}$ We present a case of a fourth ventricle SE with a spontaneous acute extra tumoral subarachnoid

Received August 10, 2012; Accepted November 1, 2012 intra-cisternal bleeding. We perform a literature review of this unusual presentation.

\section{Case Report}

A 33-year-old man, with no relevant clinical record, was admitted in our institution with 5 days history of oppressive occipital headache and posterior cervical pain. Neurologic examination revealed photophobia and neck stiffness without additional neurological focus. Laboratory test showed normal coagulation parameters. Unenhanced computed tomography (CT) scan demonstrate a well-circumscribed isointense mass located in the inferior portion of the fourth ventricle with a spontaneously hyperdense acute extratumoral hemorrhage in the cistern magna (Fig. 1). No vascular abnormalities were revealed on CT angiography. Contrast-enhanced magnetic resonance imaging (MRI) demonstrated a well-delimitated non-enhanced tumor, hypointense $\mathrm{T}_{1}$-weighted and hyperintense on $\mathrm{T}_{2}$-weighted images, involving the floor of the fourth ventricle extending caudally into cervical spinal canal via foramen magnum measuring approximately $30 \mathrm{~mm}$ in diameter (Fig. 1). 
The patient was operated immediately through a midline suboccipitalcraniectomy and a velotonsilar approach. The cistern magna was opened and hemorrhagic CSF under high pressure was aspirated sequentially. A large blood clot was removed and a firm, well delimitated, yellow-white
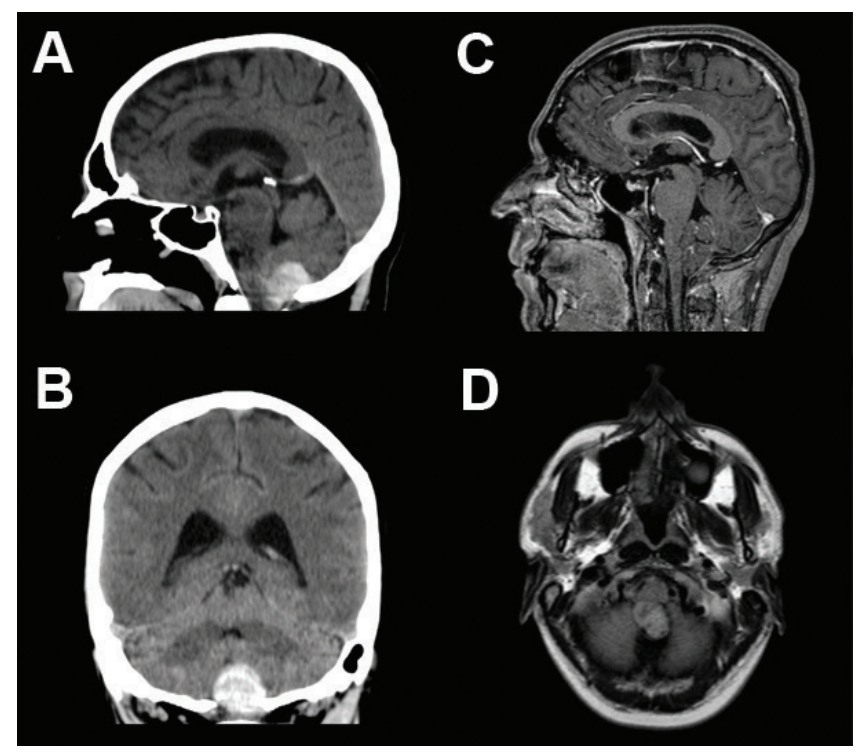

Fig. 1 A, B: shows sagittal and coronal CT views demonstrating acute extratumoral hemorrhage between the cisterna magna and the atlas. C, D: represents sagittal and axial views of a non-enhancing fourth ventricle tumor on $T_{1}$-weighted contrast MRI sequences. CT: computed tomography, MRI: magnetic resonance imaging.

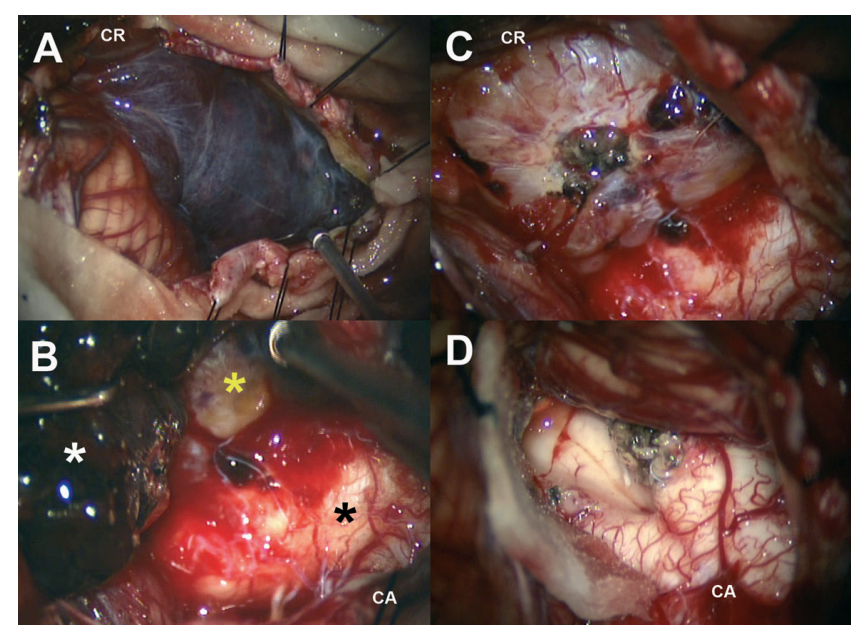

Fig. 2 A: intraoperative photo demonstrate subarachnoid hemorrhage (CR, cranial). B: white asterisk shows large blood clot, yellow revealed fourth ventricle tumor and the black asterisk mark the brain stem (CA, caudal). C: represents tumor site of hemorrhage. D: shows complete tumor excision and the fourth ventricle floor.

Neurol Med Chir (Tokyo) 53, November, 2013 partially cyst-lobulated, macroscopically hypovascular lesion was recognized and completely excised, which was attached to the right lateral recess and the floor of the fourth ventricle previous desvascularization from small branches of the right posteroinferior cerebellar artery (Fig. 2). Intra and postoperative immunohistopathological examination revealed a SE (Fig. 3). The patient has a normal postoperative course and was discharged on the fifth postoperative day. A 10-month postoperative MRI study confirmed a complete resection of the tumor with normal CSF circulation (Fig. 4).

\section{Discussion}

These benign indolent growth lesions are commonly smaller than $2 \mathrm{~cm}$ in diameter, larger tumors tend to cause symptoms related to their location. ${ }^{8,14)}$ Clinical manifestations were relatively more often caused by supratentorial lesions, $66 \%$ of these cases were symptomatic compared to $36 \%$ of patients with tumors of the fourth ventricle. ${ }^{16)}$ Large series of fourth ventricle SEs reports clinical manifestation only in one-third of the patients, especially in those arising from the floor of the fourth ventricle. ${ }^{16)}$ Loss of balance, vertigo, headache, and vomiting were the most common presenting symptom usually caused by CSF obstruction..$^{7,14,15)}$ Hemorrhage is an extremely rare sign in SEs. To our knowledge only 12 cases have been reported till date (Table 1). The etiology remains uncertain, only 4 patients had predisposing factors such as arterial hypertension, vascularized tumor, and anticoagulant therapy, ${ }^{2,4,9,18)}$

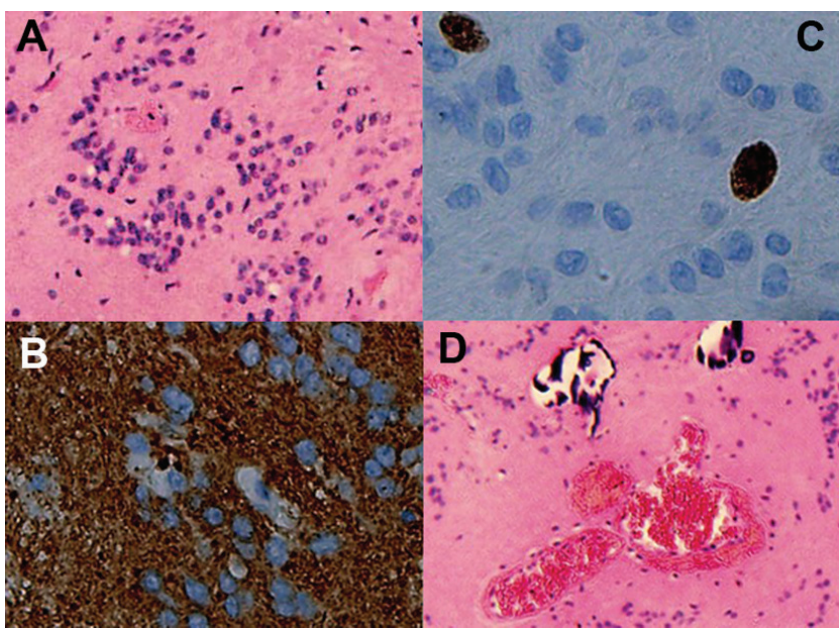

Fig. 3 A: represents clusters of isomorphic nuclei embedded in a dense fibrillary matrix of glial processes and an ependymal pseudorosette (H\&E 10×). B: shows immunoreactivity for GFAP (40x). C: revealed Ki67 label index below $2 \%(40 \times)$. D: demonstrates some lobular architecture, in an hypocellular area in a highly fibrillary background area with calcifications (H\&E 10x). H\&E: hematoxylin-eosin, GFAP: glial fibrillary acidic protein. 


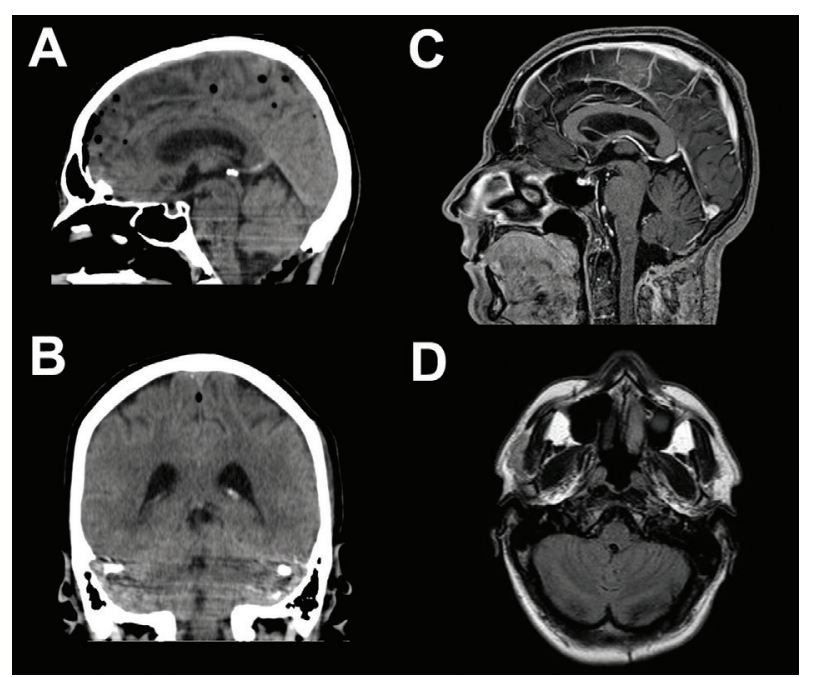

Fig. 4 A, B: shows sagittal and coronal postoperative CT views demonstrating surgical approach and hemorrhage resolution. C, D: represents $T_{1}$-weighted contrast MRI sagittal and axial views demonstrating complete tumoral resection. CT: computed tomography, MRI: magnetic resonance imaging. although some authors postulate the hypothesis that the acute extratumoral bleeding may be the result of tearing surrounding veins during tumoral growth. ${ }^{17,21)}$

Only 4 cases with subarachnoid hemorrhage (SAH) have been reported in all of them in supratentorial location. ${ }^{3,4,9,12)}$ Our case presents SAH and a large blood clot in the cisterna magna without any evidence of local veins injury but a hemorrhagic focus on tumor surface suggesting the possibility of bleeding from a tumor vessel spontaneously or as result of a traumatic mechanism due to the fact that the lower part of tumor is below the foramen magnum (Figs. 1, 2). To our knowledge, this is the first case of spontaneous acute hemorrhage in an infratentorial SE reported in the literature.

SEs first differential diagnosis are ordinary ependymomas, the former tend to extend beyond the ventricular margins, enhance markedly, and demonstrate more frequently degenerative changes such as cyst formation and calcifications. ${ }^{5,10,14,15)}$ The pathognomonic diagnosis is due to histopathological examination where SEs shows features of astrocytic and

Table 1 Case reference of hemorrhagic presentation of subependymomas

\begin{tabular}{|c|c|c|c|c|c|c|c|c|}
\hline $\begin{array}{c}\text { Case } \\
\text { no. }\end{array}$ & $\begin{array}{l}\text { Author/ } \\
\text { Year }\end{array}$ & $\begin{array}{l}\text { Age/ } \\
\text { Gender }\end{array}$ & $\begin{array}{c}\text { Clinical } \\
\text { presentation }\end{array}$ & $\begin{array}{l}\text { Predisposing } \\
\text { factor }\end{array}$ & $\begin{array}{l}\text { Location/ } \\
\text { Size }(\mathrm{cm})\end{array}$ & Hemorrhage & $\begin{array}{l}\text { Surgical approach/ } \\
\text { Resection }\end{array}$ & $\begin{array}{l}\text { Complication/ } \\
\text { Outcome }\end{array}$ \\
\hline 1 & $\begin{array}{l}\text { Scheithauer } \\
(1978)^{16)}\end{array}$ & $81 / F$ & $\mathrm{HA} / \mathrm{AC}$ & NA & LV/ Large & IT & NOP & $\begin{array}{l}\text { Massive } \\
\text { hemorrhage/died }\end{array}$ \\
\hline 2 & $\begin{array}{l}\text { Changaris et al. } \\
(1981)^{3)}\end{array}$ & $16 / \mathrm{M}$ & $\begin{array}{l}\text { HA/Blurred } \\
\text { vision }\end{array}$ & No & AT,OH/7 & IT, SAH & POTC/Total & $\begin{array}{l}\text { Homonymous } \\
\text { hemianopsia/Good }\end{array}$ \\
\hline 3 & $\begin{array}{l}\text { Seiki et al. } \\
(1984)^{17)}\end{array}$ & $33 / \mathrm{F}$ & HA/AC & No & AT/ NA & IVH & POTC/Partial & NA \\
\hline 4 & $\begin{array}{l}\text { Yamasaki et al. } \\
(1989)^{20)}\end{array}$ & $54 / \mathrm{F}$ & HA & No & $\mathrm{FH} / 5$ & IT & TC/Total & $\begin{array}{l}\text { Transient memory } \\
\text { impairment/Good }\end{array}$ \\
\hline 5 & $\begin{array}{l}\text { Marra et al. } \\
(1991)^{12)}\end{array}$ & $42 / F$ & HA & NA & $\mathrm{FH} / 2.5$ & IVH, SAH & TC/Total & No/Good \\
\hline 6 & $\begin{array}{l}\text { DiLorenzo et al. } \\
(1991)^{4)}\end{array}$ & $46 / \mathrm{M}$ & HA & AHT & $\mathrm{FH} / 4$ & IVH, SAH & FTC/Total & No/Good \\
\hline 7 & $\begin{array}{l}\text { Lindboe et al. } \\
(1992)^{9)}\end{array}$ & $63 / \mathrm{M}$ & $\begin{array}{c}\text { Disorientation } \\
\text { memory loss }\end{array}$ & $\begin{array}{c}\text { High } \\
\text { vascularized } \\
\text { tumor }\end{array}$ & $\mathrm{FH} / 5$ & $\begin{array}{l}\text { IT, IVH, } \\
\text { SAH }\end{array}$ & TC/Partial & Re-bleeding /Died \\
\hline 8 & Viale $(1994)^{19)}$ & $52 / \mathrm{M}$ & $\mathrm{HA} / \mathrm{AC}$ & $\mathrm{NA}$ & $\mathrm{FH} / 3$ & IT & NA/Total & No/Good \\
\hline 9 & $\begin{array}{l}\text { Furie and } \\
\text { Provenzale }(1995)^{5)}\end{array}$ & $46 / \mathrm{M}$ & HA & NA & $\mathrm{LV} / 2$ & IT & NA/NA & NA \\
\hline 10 & $\begin{array}{l}\text { Carrasco et al. } \\
(2010)^{2)}\end{array}$ & $71 / \mathrm{M}$ & $\mathrm{AC}$ & $\begin{array}{c}\text { AHT/ } \\
\text { Anticoagulant } \\
\text { therapy }\end{array}$ & $\mathrm{FH} / 3$ & IVH & FTC/Total & $\begin{array}{l}\text { Memory } \\
\text { Impairment/Good }\end{array}$ \\
\hline 11 & $\begin{array}{l}\text { Akamatasu et al. } \\
(2010)^{1)}\end{array}$ & $32 / \mathrm{M}$ & $\mathrm{HA} / \mathrm{AC}$ & No & $\mathrm{LV} / 2$ & IVH & FTC/total & No/Good \\
\hline 12 & $\begin{array}{l}\text { Sharma et al. } \\
(2010)^{18)}\end{array}$ & $25 / \mathrm{M}$ & $\begin{array}{l}\text { HA/ Blurred } \\
\text { vision }\end{array}$ & $\begin{array}{l}\text { Vascularized } \\
\text { tumor }\end{array}$ & $\begin{array}{l}\text { LV, AT/ } \\
\text { NA }\end{array}$ & IT & POTC/Total & $\begin{array}{l}\text { Seizures, altered } \\
\text { consciousness/Good }\end{array}$ \\
\hline 13 & Present case & $32 / \mathrm{M}$ & $\begin{array}{l}\text { HA/Posterior } \\
\text { cervical pain }\end{array}$ & No & 4 thV/3 & ICM, SAH & SOVT/total & No/Good \\
\hline
\end{tabular}

AC: altered consciousness, AHT: arterial hypertension, AT: atrium, F: female, FH: frontal horn, 4th V: fourth ventricle, FTC: frontal transcallosal, HA: headache, ICM: intra cisterna magna, IT: intratumoral, IVH: intraventricular hemorrhage, LV: lateral ventricle, M: male, NA: not available, NOP: not operated, OH: occipital horn, POTC: parieto-occipital transcortical, SAH: subarachnoid hemorrhage, SOVT: suboccipitalvelo-tonsilar, TC: transcallosal. 
ependymal differentiation with small clusters of nuclei and hypocellular areas in a highly fibrillary background, however mixed forms of SEs with ependymomas are rather common. Immunohistochemically, SEs stain diffusely with S-100 protein and glial fibrillary acidic protein (GFAP) as demonstrated in Fig. 3.

Intraoperatively SEs are generally described as hypovascularor avascular tumors, although highly vascularized cases have been reported..$^{9,10)}$ The presence of a tumor with SAH does not necessarily indicate a malignant tumor, ${ }^{3)}$ but could represent a life-threatening condition with increased risk for pre- and postoperative hemorrhage and justifies a thorough surgical planning and a promptly intervention. Large SEs often have several sites of attachment, but on the other hand these tumors can be potentially cured by surgery, a complete excision must always be attempted avoiding the damage to adjacent vital structures.

\section{Conclusion}

SEs of the fourth ventricle are commonly benign asymptomatic slow growing lesions. Symptomatic tumors should be treated surgically emphasizing the urgency in the presence of hemorrhage. The interest of this case is to demonstrate that infratentorial SEs although extremely rare, might present with acute subarachnoid bleeding.

\section{References}

1) Akamatsu Y, Utsunomiya A, Suzuki S, Endo T, Suzuki I, Nishimura S, Ezura M, Suzuki H, Uenohara H, Tominaga T: Subependymoma in the lateral ventricle manifesting as intraventricular hemorrhage. Neurol Med Chir (Tokyo) 50: 1020-1023, 2010

2) Carrasco R, Pascual JM, Navas M, Fraga J, Manzanares-Soler R, Sola RG: Spontaneous acute hemorrhage within a subependymoma of the lateral ventricle: successful emergent surgical removal through a frontal transcortical approach. Neurocirugia (Astur) 21: 478-483, 2010

3) Changaris DG, Powers JM, Perot PL, Hungerford GD, Neal GB: Subependymoma presenting as subarachnoid hemorrhage: case report. J Neurosurg 55: 643-645, 1981

4) DiLorenzo N, Rizzo A, Ciappetta P: Subependymoma of the septum pellucidum presenting as subarachnoid hemorrhage. Neurochirurgia (Stuttg) 34: 125-126, 1991

5) Furie DM, Provenzale JM: Supratentorial ependymomas and subependymomas: CT and MR appearance. J Comput Assist Tomogr 19: 518-526, 1995

6) Gandolfi A, Brizzi RE, Tedeschi F, Paini P, Bassi P: Symptomatic subependymoma of the fourth ventricle. Case report. J Neurosurg 55(5): 841-844, 1981.

7) Jooma R, Torrens MJ, Bradshaw J, Brownell B: Subependymomas of the fourth ventricle. Surgical treatment in 12 cases. J Neurosurg 62: 508-512, 1985
8) Kurukumbi M, Muley A, Ramidi G, Wynn Z, Trouth AJ: A rare case of subependymoma with an atypical presentation: a case report. Case Rep Neurol 3: 227-232, 2011

9) Lindboe CF, Stolt-Nielsen A, Dale LG: Hemorrhage in a highly vascularized subependymoma of the septum pellucidum: case report. Neurosurgery 31: 741-745, 1992.

10) Lobato RD, Sarabia M, Castro S, Esparza J, Cordobés F, Portillo JM, Rivas JJ: Symptomatic subependymoma: report of four new cases studied with computed tomography and review of the literature. Neurosurgery 19: 594-598, 1986

11) Lombardi D, Scheithauer BW, Meyer FB, Forbes GS, Shaw EG, Gibney DJ, Katzmann JA: Symptomatic subependymoma: a clinicopathological and flow cytometric study. J Neurosurg 75: 583-588, 1991

12) Marra A, Dario A, Scamoni C, Cerati M, Crivelli G, Dorizzi A: Intraventricular subependymoma presenting as subarachnoid hemorrhage. Case report. J Neurosurg Sci 35: 213-215, 1991

13) Nishio S, Morioka T, Mihara F, Fukui M: Subependymoma of the lateral ventricles. Neurosurg Rev 23: 98-103, 2000

14) Ragel BT, Osborn AG, Whang K, Townsend JJ, Jensen RL, Couldwell WT: Subependymomas: an analysis of clinical and imaging features. Neurosurgery 58: 881-890; discussion 881-890, 2006

15) Rushing EJ, Cooper PB, Quezado M, Begnami M, Crespo A, Smirniotopoulos JG, Ecklund J, Olsen C, Santi M: Subependymoma revisited: clinicopathological evaluation of 83 cases. J Neurooncol 85: 297-305, 2007

16) Scheithauer BW: Symptomatic subependymoma. Report of 21 cases with review of the literature. J Neurosurg 49: 689-696, 1978

17) Seiki Y, Terao H, Shibata I, Tsukahara K, Tsutsumi S, Kudo M: [A case of subependymoma in the lateral ventricle with intraventricular hemorrhage]. No Shinkei Geka 12: 761-765, 1984 (Japanese)

18) Sharma M, Velho V, Ghodgaonkar P, Palande DA: Symtomatic subependymoma of the lateral ventricle: arare entity-a case report and review of literature. Internet J Neurosurg 7: 7, 2010

19) Viale GL: Subependymomas of the lateral ventricles. $\mathrm{Br} J$ Neurosurg 8: 765-767, 1994.

20) Yamasaki $T$, Kikuchi $H$, Higashi $T$, Yamabe H, Moritake K: Two surgically cured cases of subependymoma with emphasis on magnetic resonance imaging. Surg Neurol 33: 329-335, 1990

21) Yuguang L, Meng L, Shugan Z, Yuquan J, Gang L, Xingang L, Chengyuan W: Intracranial tumoural haemorrhage-a report of 58 cases. J Clin Neurosci 9: 637-639, 2002

Address reprint requests to: Federico Landriel, MD, Department of Neurosurgery, Hospital Italiano de Buenos Aires, Juan D. Perón 4190, Buenos Aires C1181ACH, Argentina. e-mail: fedelandriel@gmail.com 